LIST OF NORTH AMERICAN LAND AND FRESH.WATER SHELLS RECEIVED FROM THE U. S. DEPARTMENT OF AGRICULTURE, WITH NOTES AND COMMENTS THEREON.

\author{
$\mathrm{BY}$ \\ Robert E. C. Stearns, \\ Adjunct Curator of the Department of Mollusks.
}

The following list includes a number of molluscan forms received at various times by the U. S. National Museum from the above Department, being the collections made by Dr. C. Hart Merriam, in charge of the Division of Biological Explorations, and by his assistants, during the years 1889-90. The list contains the names of a few species not before collected, which have been described by the writer in a previous volume of the Proceedings of the National Museum ; and further, many interesting facts pertaining to the geographical distribution of some of the forms not before made known.

\title{
Class GASTROPODA.
}

Order PULMONATA.

Sub order GeоpHiLA.

Glandina decussata Desh.

Painted Cave, mouth of the Pecos River, Texas. William Lloyd. (Mus. No. 118385).

Two examples of the above were detected at this locality; one fresh and in fine condition, the other bleached and broken. The species seems to be tolerably well characterized for a Glandina, though there is scarcely a doubt that too many have been made in this group.

\section{Vitrina pfeifferi Newc.}

Bridger's Pass, Wyoming, "near a spring in the cañon ;" several examples. V. Bailey (Mus. No. 118484.)

Helix (Patula) striatella Anth.; var. Cronkhitei Newc.

Bridger's Pass, Wyoming, edge of a "spring in the cañon." V. Bailey. (Mus. No. 118481.) 
Helix (Patula) strigosa Gld.

Wyoming, Bridger's Pass, May, 1890 (Mus. No. 118374) ; also in the Uintah and Wahsatch Mountains at Park City, Utah, June, 1890. Vernon Bailey. (Mus. No. 118371.)

Several characteristic examples were found by Mr. Bailey "on the hills along the cañon" at the first-named locality.

Helix (Patula) hemphilli Newc.

Needle Peak, Lost River Mountains, Idaho, " among rocks at an altitude varying from 8,000 to 11,000 feet." Bailey \& Dutcher, August, 1890. (Mus. No. 118392.)

Several examples of this form, now regarded as an extreme variety of the protean strigosa, were detected as above by Dr. Merriam's collectors. Compared with the typical strigosa, its relations are analogous

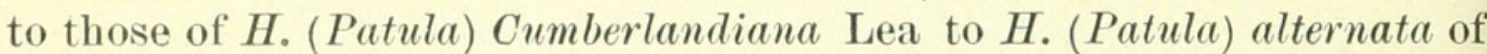
Say. Of the direct gradation of the alleged species, more properly intermediate and blending varieties, to which the names of Fergusoni mordax and Cumberlandiana have been given, it may be said that a sufficiently large series tells its own story, and the examples in the National Museum point to such a connection.

\section{Helix (Polygyra) texasiana Mor.}

Texas, near Sanderson (Mus. No. 118364); vicinity of Eagle Pass (Mus. No. 120346); Comstock (Mus. No. 118401); also at Painted Cave, near the mouth of the Pecos (Mus. No. 118390). William Lloyd. Del Rio, on dry land in the valley of the Rio Grande (Mus. No. 118369), Vernon Bailey.

Several examples of the flat variety of this well-known snail shell, with the sculpture only moderately developed, were obtained at Sanderson. The others are as usual as to elevation and sculpture.

Helix (Pomatia) humboldtiana Val.

Texas, at Altuda, at an elevation of 5,000 feet, where it, a single specimen in fair condition, had been thrown out with soil by a prairie dog. (Mus. No. 118366.) William Lloyd.

This species has not before been reported from any locality within the territory of the United States. It was described from Mexico where it is found in the neighborhood of the City of Mexico and in other localities. The national collection contains several examples from the Real del Monte. It has a pretty close resemblance to some of the varieties of the European $H$. (Pomatia) pomatia, and it may possibly be an introduced form. H. pomatia has for centuries been esteemed as an article of food in various parts of Europe, and was regarded as a dainty by the ancient Romans. It was propagated and raised in large quantities for their use and specially fed on certain plants to give the flesh a particular flavor.

Unmistakable specimens of another favorite edible snail common to Europe, H. (Pomatia) aspersa, is found in Mexico, and examples from 
Puebla, in the province of Puebla, Mexico, were presented to the National Museum by the Mexican Geographical Commission a few years ago. The presence of these two forms most certainly suggests the question as to whether they were not introduced by the Spaniards many years, centuries ago, either for food purposes or incidentally in the routine and accidents of commercial intercourse.

\section{Helix (Arionta) coloradoensis Stearns.}

Grand Cañon of the Colorado, opposite the Kabab Plateau, at an elevation of 3,500 feet (Mus. No. 104100). Dr. C. Hart Merriam.

Described in the Proceedings of the U.S. National Museum, vol. XIII, p. 206, Figs. 6, 7, 8, Pl. xv.

\section{Helix (Arionta) magdalenensis Stearns.}

Magdalena, State of Sonora, Mexico, on the line of the Sonora, New Mexico and Arizona Railroad, at an elevation of 1,000 feet above the town (Mus. No. 104094); Vernon Bailey.

Described in the Proceedings of the U. S. National Museum, vol. XIII, p. 207-208, Figs. 11, 12, 13, Pl. xV.

\section{Bulimulus dealbatus Say.}

Texas, near Sanderson (Mus. No. 118365); also from near Eagle Pass (Mus. No. 120345). William Lloyd.

Three examples of a small variety of this form, of which one individual, in the prominence of its incremental lines, indıcates the relationship of Mr. Pilsbry's B. ragsdalei. The foregoing applies equally well to the Eagle Pass examples, six in number. The Sanderson specimens are of a dead, chalky whiteness; the Eagle Pass lot are marked more or less with irregular blotchy stripes of a pale corneous brown color.

Bulimulus dealbatus Say; var. $=$ B. ragsdalei Pilsbry.

Comstock, Texas, William Lloyd (Mus. No. 118402); Langtry, in the same State, Vernon Bailey (Mus. No. 118367).

Four specimens of this variety of dealbatus were collected at the firstnamed locality. These differ from Mr. Pilsbry's shells only in the matter of color, the examples beforc me being of an opaque white, with an occasional pale brownish longitudinal streak. The largest individual shows considerable angulation on the basal whorl just below and following the suture, and thero is considerable variation in robustness. The longitudinal ribs consist of more or less strongly developed growth lines, which are distinct and definite throughout and over the entire shell in Mr. Lloyd's specimens; more conspicuous in the largest example, which is the one above referred to as showing angulation. The author says of B. ragsdalei, " that no specimens showing a transition to $B$, deal-

Proc. N. M. $91-7$ 
batus or schiedeanus were found, nor have I ever seen any, although I have collected thousands of Bulimuli in Texas," etc.

The National Museum is indebted to Mr. Pilsbry for an example of the original lot from Montague County, Texas (Mus. No. 118361), in which the sculpture described by the author is so sharply developed, that without intervening and connecting specimens it might well be regarded as a new form.

With his specimen and comments before me, I was led to examine the large geographical series of dealbatus and related species, and found that in certain examples from Texas (Mus. No. 26411) collected by Dr. Shumard many years ago, the upper whorls of two, and nearly the whole of the third, show this ribbing; in the first two the corneous ground color prevails. In another lot, also from Texas, collected years ago by General (then Lieutenant) Couch, U. S. Army, the specimens are unusualiy elongated (No. 26415), and one of them exhibits conspicuous growth lines. In two examples (No. 29614), of rather delicate texture, the corneous character and coloration dominates, with opaque longitudinal streaks of whitish color; the upper whorls in these are ribbed. The same also in four specimens (No. 30696) from Texas, collected by Lieutenant Beale. In another tube (No. 31625) three of the eight specimens are ribbed. Three out of eight examples from Leon, Texas (No. 26410), exhibit this feature, and two out of five from Dallas, Texas (No. 26413), have the same sculptural peculiarity.

In specimens from Clifton, Texas (No. 30240), the upper whorls are ribbed, and the ribbing continues down to and upon the upper part of the basal whorl just below the suture. So in examples from San Felipé Springs (No. 26569), collected by Lieutenant Beale, six of the seven may be regarded as the variety ragsdalei.

Mr. C. T. Simpson collected specimens in Limestone Gap, Indian Territory (No. 101062), and four of the examples show distinct ribbing on the upper whorls; so also with specimens from Matamoras, Mexico (U. S. Mus. No. 26407), of alternatus, two specimens, and others from Tamaulipas, Mexico (No. 26566), of this last named species.

A single example of the variety ragsdalei was collected by $\mathrm{Mr}$. Bailey, who detected it in a cañon of the Rio Grande at Langtry, Texas. B. ragsdalei suggests the Asiatic form B. abyssinicus Ruppel $(?=$ B. fairbanksi Blfd.), from Bombay, which not unlikely sometimes occurs with inconspicuous growth lines like the ordinary form of dealbatus. When the physical peculiarities of the region inhabited by dealbatus, alternatus, etc., are considered we may reasonably look for a wide range of variation in form, size, sculpture, etc., and it is highly probable that individuals, if not colonies, with more striking characteristics than any yet collected, will sooner or later be discovered. 
Bulimulus alternatus Say.

= Bulimus alternatus Say, 1830 .

+ Bulimus Schiedeanus Pfr., 1854.

+ Bulimus patriarcha W. G. B., 1858.

+ Bulimus maria Albers, 1858.

+ Bulimus mooreanus Pfr., 1868.

The last four names which have been given to this exceedingly variable form I regard as synonyms, and an examination of the ample material in the national collection points to and warrants this conclusion. I am under the impression that Mr. Binney is now of this opinion. Mr. J. A. Singley, of Giddings, Texas, and Mr. C. T. Simpson, of the National Museum, who have collected large numbers of these so-called species in Texas and the Indian Territory, consider the foregoing, as well as B. dealbatus Say, as one and the same species. I am not prepared to go quite so far at the present moment; perhaps further comparison and study may lead me to the same conclusion. The synonyms may be regarded as representing varietal aspects, and it is not surprising that so mutable a form should have received so many names. The years in which these descriptions were published, taken from Binney's Manual, , have been given for the convenience of students. Distribution: Indian Territory, Texas, Louisiana, Mexico.

Dr. Merriam's collectors have found it in the following places in Texas: Painted Cave, mouth of the Pecos River (Mus. No. 118386); Comstock (Mus. No. 118400), near Eagle Pass (Mus. Nos. 120343, 120344), William Lloyd ; in the valley of the Rio Grand e, "at Del Rio, among brush on high ground that is never flooded " (Mus. No. 118370); also at Langtry (Mus. No. 118368), Vernon Bailey.

The specimens collected by Mr. Bailey at Del Rio include examples with a dull chalk white and others with a smooth porcelaneous surface with an occasional individual faintly colored with yellowish brown in obseure irregular longitudinal bands. The color of the aperture varies from nearly white, yellowish, and yellowish brown to dark chocolate. Some examples are robust, others elongated. Some approach the form to which Mr. Binney gave the name patriarchus, others are nearer to dealbatus. The shells vary much in solidity, some being thicker and heavier than others. In most instances the columella is simple without a wave, subplait, or fold; this part of the shell being straight, while in others the pillar exhibits a partial twist, suggesting a fold or modified plait. The umbilical feature is also variable, being more open in some specimens than in others. The deposit of callus on the pillar is sometimes so heavy as to connect the edges of the outer lip and produce a peristome. In some the incremental lines are fine, in others coarse, and occasionally a specimen is met with that is partially traversed by a fine grooved line parallel to and just below the suture. The finest examples in the National Museum were collected at Painted 
Cave by Mr. Lloyd, and are of unusual size. The remarks foilowing Mr. Bailey's Del Rio specimens apply equally well to these.

Holospira Roemeri Pfr.

Painted Cave, mouth of the Pecos River, Texas. (Mus. No. 118388.) Two examples; also in the Devil's River region, Texas, a single specimen (Mus. No. 118393). William Lloyd.

Number of whorls, varying from thirteen to sixteen, and the specimens also show some difference in robustness.

Previously reported from Texas by Mr. W. G. Binney, who also notices the point that some individuals are more ventricose than others, and that the number of whorls varies from "twelve to fourteen."

\section{Holospira arizonensis Stearns.}

Dos Cabezas, Arizona, two specimens and numerous fragments collected by V. Bailey November, 1889 (Mus. No. 104392).

Described in the Proceedings of the United States National Museum, pp. 208-11, vol. XII, Figs. 2, 3, Pl. xv.

\section{Succinea luteola Gould.}

Texas, Painted Cave, mouth of the Pecos River, William Lloyd (Mus. No. 118391). Arizona, near Wilcox, on dry alkali flats, November, 1889, Vernon Bailey (Mus. No. 118373).

The bleachen aspect resulting from these alkaline and arid stations is also seen in examples of Succinea that inhabit sandy reaches along the seaboard where the vegetation is sparse and its substance ligneous rather than succulent and more saline than in places farther from the sea.

$$
\text { Succinea avara Say. }
$$

Bridger's Pass, Wyoming, "near a spring in the cañon." V. Bailey (Mus. No. $118483)$.

\section{Succinea campestris Say.}

Texas, near Sanderson, William Lloyd (Mus. No. 118363).

\section{Suborder HyGropHILA.}

Limnæa stagnalis Linn.

Nevada, various places.

This well known European species, like its congener L. palustris, has a wide distribution in North America. We are indebted to Mr. Bailey for specimens from the East Humboldt River at Elko, Nevada (Mus. No.120910), also from the same stream near Battle Mountain, Nevada (Mus. No. 120909).

\section{Limnæa palustris Müll.}

Nevada, Idaho, California, Arizona, etc.

The exceedingly wide distribution of this form is well known. It may be regarded as the parent stock from which a great number of varieties 
have originated, many of which have received specific names. Mr. Binney* has included several of these alleged species in the synonymy of palustris and many more will have to be added whenever a thorough revision of the Limncide and related groups is made. Mr. Binney has also given several figures which serve to show the variability of this protean form, but as many more would hardly represent the intermediate aspects.

The commoner West American variety of the above is generally known to collectors as Limnoa Nuttalliana Lea (Mus. No. 104095). It was found in great abundance in Walker Lake, San Francisco Mountain, Arizona Territory, by Dr. Merriam in 1889. This lake occupies the crater cavity or basiu of an extinct or passive volcano, and the elevation of the lake is about 8,250 feet above the sea level. Mr. Bailey collected palustris in the Uintah Mountains (Mus. No. 118376), where he detected it "in a creek at an elevation of 10,000 feet."

A single low-spired and rather ventricose example of this species, close to specimens from southern Utah collected by Dr. Yarrow (Mus. No. 47770), and quite black and malleated, like specimens from Ione Valley, California, collected by C. D. Voy (Mus. No.47690), was found by Dr. Merriam's collectors in Saw-tooth Lake, Idaho, in September, 1890. One example exhibits a serial regularity in the malleation suggestive of rude obsolete spiral ribbing, stronger on the basal whorl (Mus. No. 120354).

Several living examples, dwarfed but apparently mature, were also collected in Salmon River near Challis, Idaho, by Merriam and Bailey (Mus. No. 120356). They are all of a dark amber color and quite uniform in size. The more ventricose individuals approach closely to certain specimens of $L$. Adeline Tryon, and are, save in color, like the examples of L. palustris collected by Mr. Dall some years ago at Bay View, near San Francisco (Mus. No. 43321). Mr. Vernon Bailey collected several specimens in Nevada, in East Humboldt River near Elko (Mus. No. 120912); also in the same stream near Battle Mountain (Mus. No. 120911).

Mr. Dall has recently collected an interesting variety of this species in the irrigation ditches near Hot Springs, in Honey Lake Valley, Lassen County, California, which is within the area of the extinct Tertiary Lake Lahontan (Mus. No. 1185̃61). Mr. Dall's shells exhibit a most delicate sculpture, composed of very fine and close setincremental lines crossed by transverse and somewhat waved and slightly incised grooves, much resembling the delicate sculpture of some of the Mexican Glandinas. This peculiar sculpture is not infrequent in other species of Limnaca; notably in L. lepida Gould, L. ampla Mighels, L. Sumassi Baird, and occasionally in $L$. columella Say, L. caperata Say, and $L$. lanceata Gould, and sometimes most likely in other species of the group.

* Land and Fresh-water Shells of North America, Part II, Series 2, Misc. Coll, 143. 


\section{Limnæa lepida Gould.}

Idaho, Salmon River, near Challis, September, 1890 (Mus. No. 120351). Merriman and Bailey.

A single example, distinctly characteristic, as seen at once by a comparison with the type (Mus. No. 5541) in the national collection from Oregon.

The form, to which Lea's name Nuttalliana is usually attached, and which is so abundant on the west coast in California and the other Pacific States, and which frequently attains a large size, is really a maximum aspect of Gould's lepida, and is specially noticeable for the expanded or effuse aperture. As Lea's name has priority of 6 years, it may be more proper to say that Gould's lepida is a local and varietal form of Nuttalliana. Without extending this comment further as to the relationship of these with palustris, the main difference as between typical lepida and Nuttalliana is the more sturdy aspect and flaring mouth of the latter; as to where Nuttalliana ieaves off and palustris begins it would be inconvenient to demonstrate at this time. Mr. Binney has included Iea's species in his synonymy of palustris, and I do not hesitate to concur in this arrangement.

\section{Limnæa Adelinæ Tryon.}

Idaho, Salmon River, near Challis, September, 1890. Merriam and Bailey. (Mus. No. 120353.)

Two examples hardly mature of the form to which Tryon gave the above name and agreeing with the types from near San Francisco, California (Mus. No. 24879).

\section{Planorbis trivolvis Say, var.}

Nevada, East Humboldt River, near Battle Mountain (Mus. No. 120915), Elko from the same stream (Mus. No. 120916). Vernon Bailey.

A few examples of the above, approaching the corpulentus aspect, with sharply defined incremental sculpture, were obtained at the above localities.

\section{Planorbis trivolvis Say, var.}

$=P$. plexata Ingersoll.

Idaho, Saw Tooth Lake, October, 1890 (Mus. No. 120348), Merriam \& Bailey.

The varietal aspect is exhibited in the distorted twist in the coil of the earlier whorls. This distortion, which is shown by all the examples, eight in number, does not continue to or affect the shape of the aperture, for, curiously enough, the animal, as maturity approaches, gets back, if I may use the expression, to the ordinary or symmetrical plane of coil.

\section{Planorbis tumens Cpr.}

Arizona Territory, at Phœnix (Mus. No. 103623), Mr. Bailey.

This species, described from Mazatlan specimens, suggests the more southern texture and general facies of Planorbis, and recalls P. tumidus Pfr., so abundant in Guatemala and Nicaragua. 
Planorbis tumidus Pfr.

Texas, Devil's River, several examples (Mus. No. 118396), William Lloyd.

Planorbis liebmani Dkr.

Texas, Devil's River, one specimen (Mus. No. 118398), William Lloyd.

Planorbis (Gyraulus) parvus Say.

Arizona, Walker's Lake (Mus. No. 103625), Dr. C. Hart Merriam ; Devil's River (Mus. No. 118397), W. Lloyd.

A single example of this characteristic species was found among the numerous specimens of Linncea muttalliana collected by Dr. Merriam in the crater bowl of Walker Lake, San Francisco Mountain, during his biological exploration of the region in 1889. The national collection also contains examples from th is territory, collected by Dr. Edward Palmer, and General Carlton collected it on the Colorado Desert, California, where also I detected it near Indio and at other places along the line of the Southern Pacific Railroad, in 1884.

Physa heterostropha Say.

Arizona Territory, at Phœnix (Mus. No. 100851); Magdalena, Northwest Mexico (No. 103622); Idaho, Birch Creek (No. 120347); Nevada, East Humboldt River (Mus. Nos. 120907 and 120908), Vernon Bailey.

Several examples, for the most part immature, were obtained at Phœnix by Mr. Bailey, who detected them in an irrigation ditch " among moss." The Mexican examples were also found in a similar situation.

In the course of its southerly distribution this widely diffused form has been the recipient of many specific names, apparently induced more by the occult influence of politico-geographical lines upon the describer than any special differential facies of the shells themselves.

From other southerly regions the Museum series indicates the following localities: Hot Springs, Lower California (No. 47753), H. \&.C. R. Oreutt, March, 1882 ; Mexico, Puebla, Puebla ; and Mizantla, Vera Cruz, Mexican Geographical Commission.

The Nevada specimens collected by Mr. Bailey (No.120907) were from Elko. Of these there are several examples, some of which approach the form named ampullacea by Dr. Gould. The specific name heterostropha was published by Say in 1817 under Limnca. Subsequently, in 1821, P. gyrina was described and published.

A large series demonstrates that these alleged species interblend and merge the one into the other, so that the application of one of these names more than the other is altogether arbitrary or eapricious; but as heterostropha has four years' priority over gyrina, the former name must supersede and include the latter, as well as a great many other specific names at present in use, whenever a revision of this group is made.

Physa gyrina Say.

Texas, Pecos River, near Painted Cave (Mus. No. 118387). William Lloyd.

Three fresh and perfect specimens. 
Physa osculans Hald.

Arizona, Devil's River (Mus. No. 118395), William Lloyd ; Del Rio, Rio Grande Valley (Mus. No. 118375), Vernon Bailey.

\section{Order PROSOBRANCHIATA.}

Suborder Pectenibranchiata.

Section TæNioglossa.

Fluminicola nuttalliana Lea.

Idaho, Salmon River, near Challis (Mus. No. 120352), Merriam \& Bailey.

\section{Suborder SCUTIBRANCHIATA.}

Section RHIPIDOGLOSSA.

Helicina orbiculata Say.

Painted Cave, mouth of the Pecos River, Texas, William Lloyd. Two specimens (Mus. No. 118389).

The extensive series in the national collection indicates the wide distribution of this species. From the northerly line of Indian Territory (C. T. Simpson) and middle Tennessee it extends through Arkansas and Texas, Mississippi and Louisiana, to the shores of the Gulf of Mexico at Galveston, Indianola, and elsewhere; also as far south as Tamaulipas, in Mexico; in Georgia, on the Atlantic coast; thence southward to Florida, where it has been detected by myself and others at various places. I found it under a cedar $\log$ between Tampa City and Rocky Point in February, 1869.

\section{Class PELECYPODA.}

\section{Order TETRABRANCHIA. \\ Suborder Submytillacea. \\ Unio coloradoensis Lea.}

Mouth of the Pecos River, a single right valve of a half-grown individual. William Lloyd.

\section{Unio tampicoensis Lea.}

Mouth of the Rio Pecos, two left valves, adult, were obtained by Mr. Lloyd.

\section{Unio Popei Lea.}

Devil's River, Texas (Mus. No. 118394); also Rio Salado, near Leon, Mexico (Mus. No. 120920), William Lloyd.

A fresh specimen of this rare species was found as above by Mr. Lloyd. The late Dr. Lea described it from specimens collected by Berlandier in the Devil's River several years ago, and the Lea collection in the National 
Museum (No. 85895) also contains specimens from the Rio Salado, New Mexico, collected by Lieutenant Beale. It varies in color externally from blackish brown to olivaceous green, with hints of radiating markings of lighter shade. The nacre is notably iridescent, lustrous, and translucent in Lloyd's Devil's River specimen.

\section{Unio umbrosus Lea.}

Mexico, in the Rio Salado, near Leon, January, 1891, William Lloyd (Mus. No. 20919).

A single large, heavy example, exceeding in size and weight the largest in the Lea collection. Dr. Lea's specimens were from the Medellin River, Mexico.

\section{Unio camptodon Say.}

$=U$. mamubius Gonld.

$=U$. symmetricus Lea.

$+U$. jamesianus Lea.

Texas, Sous Creek, Los dos Hermanos, November, 1890, William Lloyd (Mus. No. 120921).

In the three examples coliected by Mr. Lloyd we have the aspect of camptodon to which Mr. Lea gave the name symmetricus. Of the four specific names, Mr. Say's has priority; as to the propriety of regarding the others as synonyms, there is no question in the face of a comparison of the specimens in the national collection.

A varietal position is the utmost that can be conceded to these socalled species. The distribution of the form or forms of camptodon is principally southern. Without presenting in this place an exhaustive exhibit of localities as shown by the material in the national collection, it is sufficient to state that the first, camptodon, has been collected and credited to southern Illinois, in the north. Say described it from New Orleans, Louisiana; Gould's manubius, to Chihuahua, Mexico ; Lea's symmetricus, to Red River, Louisiana; and the same author's Jamesianus, to Jackson, Mississippi.

\section{Margaritana margaritifera Linn.}

Nevada, East Humboldt River, October, 1890, Vernon Bailey (Mus. No. 120349); California, Plumas County, W. H. Dall (Mus. No. 118559).

A single example, with nacre bluish to reddish purple, collected by Mr. Bailey. Mr. Dall collected specimens in the Sierra Nevada, near Devil's Corral, Plumas County, California, at an elevation of 5,200 feet abore the sea. The nacre a dull purple.

It is interesting to note the hypsometrical distribution of this widespread form which is found geographically diffused over the northernmost portions of the three continents, Europe, America, and Asia. It reaches an altitude higher than any of the tooth-hinged freshwater mussels, and in this feature of its distribution equals a few of the Anodons. Mr. Dall's specimens, I am inclined to believe, are from a greater altitude than heretofore reported. 
Anodonta Nuttalliana Lea.

+ A. Wahlamatensis Lea.

+ A. Oregonensis Lea.

+ A. Californiensis Lea.

Numerous examples, generally odd valses of dead shells, including the two varieties which correspond to Dr. Lea's types of his Nuttalliana and Californiensis, were obtained in the East Humboldt River, near Battle Mountain (Mus. No. 120906), also from the same stream at Elko, Nevada (Mus. No. 120905), by Mr. Bailey. The forms Oregonensis, in which the dorsal wing is the least developed, and Wahlamatensis, which exhibits this feature conspicuously, were not distinctly represented in the lots from these places, in the mature form, though in certain valves the earlier zones of growth indicate the outlines which characterize the varieties of Nuttalliana to which Dr. Lea applied these last two names.

Anodonta imbecilis Say.

Devil's River, Texas, William Lloyd (Mus. No. 118399).

Several examples of this delicate species, so like varieties of the European anatina as to be difficult of separation, were found as above by Mr. Lloyd. A. anatina is otherwise represented elsewhere in North America by A. fluviatilis and other alleged species.

Sub-order Conchacea.

Sphaerium dentatum Hald.

Nevada, East Humboldt River, at Elko (Mus. No. 120913), and near Battle Mountain, in the same stream (Mus. No. 120914), Vernon Bailey.

Pisidium occidentale Newc.

Bridger's Pass, Wyoming, "in a spring in cañon," Vernon Bailey (Mus. No. 118482), 


\section{$2 \mathrm{BHL}$ Biodiversity Heritage Library}

Stearns, Robert E. C. 1891. "List of North American land and fresh-water shells received from the U. S.Department of Agriculture, with notes and comments there on." Proceedings of the United States National Museum 14(844), 95-106. https://doi.org/10.5479/si.00963801.844.95.

View This Item Online: https://www.biodiversitylibrary.org/item/32426

DOI: https://doi.org/10.5479/si.00963801.844.95

Permalink: https://www.biodiversitylibrary.org/partpdf/11468

\section{Holding Institution}

Smithsonian Libraries

\section{Sponsored by}

Smithsonian

\section{Copyright \& Reuse}

Copyright Status: NOT_IN_COPYRIGHT

This document was created from content at the Biodiversity Heritage Library, the world's largest open access digital library for biodiversity literature and archives. Visit BHL at https://www.biodiversitylibrary.org. 